\title{
Job Satisfaction of Faculty Members of Universities in Pakistan: A Case Study of University of Sindh-Jamshoro
}

\author{
Anwar Ali Shah G. Syed ${ }^{1}$, Nadeem Bhatti ${ }^{2}$, Sabir Michael ${ }^{3}$, Faiz M. Shaikh ${ }^{4} \& \operatorname{Hina~Shah~}^{5}$ \\ ${ }^{1}$ Business Administration \& Pro-Vice Chancellor, University of Sindh, Jamshoro, Pakistan \\ ${ }^{2}$ Head of Faculty, North American College, Toronto, Ontario, Canada \\ ${ }^{3}$ PAF, KIET, Karachi, Sindh, Pakistan \\ ${ }^{4}$ SZABAC, Dokri, Larkana, Sindh, Pakistan \\ ${ }^{5}$ HOD, Department of Commerce Govt. Girls College Hyderabad, Sindh, Pakistan \\ Correspondence: Anwar Ali Shah G. Syed, Business Administration \& Pro-Vice Chancellor, University of Sindh, \\ Jamshoro, Pakistan. E-mail: dr_anwar_shah@yahoo.com
}

Received: May 27, 2012

doi:10.5539/mas.v6n7p89
Accepted: June 14, 2012 Online Published: June 26, 2012

URL: http://dx.doi.org/10.5539/mas.v6n7p89

\begin{abstract}
The current research investigates the Job satisfaction of faculty members of Universities in Pakistan: A case study of University of Sindh-Jamshoro. Data were collected from 300 faculty members by using simple random techniques. A structural uestionnaire was developed for the reliability and validity of the Data. Data were analyzed by using SPSS 18 version software. Faculty satisfaction is the most significant aspect in university education. If features accountable for dissatisfaction can be distinguishe and attempt can be made either to change those circumstances or may reduce their impact on satisfaction, obviously it enhances teacher's performance. Faculty satisfaction is important for the improvement, efficiency and effectiveness of the upper education system. To understand the concept it is necessary to study that what aspect influence upon faculty's satisfaction. Rationale of this conceptual study is to observe teacher's satisfaction at Universities in Pakistan. Which is revealed by Herzberg motivation and hygiene factors and the factors such as personal life? The study also explores the effects of these factors on faculty's work satisfaction with respect to their demographic characteristics. It was revealed that female faculty members are more satisfied compare with male faculty members. The faculty members in Univeersity of Sindh are most satisfied with their jobs. It was further revealed that faculty members in University of Sindh Jamshoro are more concerned about the issues of derth in security in the campus and various political pressures of students.
\end{abstract}

Keywords: job satisfaction, motivational, hygiene factors, personal characteristics

\section{Introduction}

University of Sindh Jamshoro is one of the oldest university in Pakistan, Currently more than seven hundred faculty members are working in various deprtments. This study presented practical implication to motivate faculty members of University of Sindh jmshoro and to enhance their quality of works. In addition this also purposes the helpful suggestions for management to motivate their faculties and benefit from productive result of their organizations performanceScholars, management experts, and educationist are agreed that faculty's satisfaction is a critical attitude which plays a key role in student's successful and bright future. Therefore the awareness about the factors influencing upon faculty's satisfaction at work place has great importance for a successful learning system. Validated measure of employee's satisfaction is the most important information relating to human resources in an institute (Roznowski \& Hulin, 1992). Behavioral and social sciences indicated that there is positive relationship between work satisfaction and employee performance (Bowran \& Todd, 1999). Pearson and Seiler (1983) investigated in academician's satisfaction level with their working environment to the context of Hertzberg theory. They found that academicians were satisfied with their working environment but dissatisfied with compensation. Manger and Eikeland (1990) postulated that relationships with co-workers have direct impact on employee's turnover. They found that academicians those who are not satisfied with intrinsic factor are intended to leave their jobs so economic resources do not make reason to continue or leave the job. Such studies gave us an idea about those factors which motivate employees to stay in organization or to quite. 
Good knowledge and understanding of employee satisfaction lead to employee's motivation and firm performance which is positively correlated with student's achievement.

Recently employee's satisfaction has turn into widespread observable fact in organizations where supervision is too much worried about physical and emotional well-being of working class (Spector, 1997).

\section{Job Satisfaction}

Thousands of studies have been conducted on teacher's satisfaction, worker's commitment, employee's performance and worker's participation. These all variables are mutually dependent on each other. Work satisfaction is manner (Weiss, 2002; Brief, 1998) an affective reaction (Cranny, Smith, \& Stone, 1992) and pleasant affecting situation ensuring by employees work (Locke, 1976) So employee's satisfaction is an important factor that motivates individuals to perform effectively and efficiently towards organization's goals, and give a rush every time to face new challenges during their work. Employee's satisfaction closely links with job motivation, but not the same as motivation itself. Organizations measure and evaluate employee satisfaction that improves their performance, quality of work and also assure low turnover and low absenteeism rate of employees. According to Manger and Eikeland (1990) the factor like peers relationship has the strongest impact on academics satisfaction and intent to leave According to the Islamic teaching "Allah (God) likes hard worker" (Holly Quraan). Employee must be paid before vanishing his or her perspiration (Hazrat Muhammad PBUH). Job satisfaction is very an important attitude in Islamic point of view. According to Brief (1998) there were 3333 articles and dissertations published on job satisfaction in 1976, and 12400 in 1994. Job satisfaction of employees has an essential role in organizations, because satisfied employees are the valuable assets of any organization. Job satisfaction has become an important point for researchers (Gautam, Mandal, \& Dalal, 2006). Particularly in teaching profession, satisfied teachers are important predictor students, educational institutes as well as the whole nation. Because they contribute their efforts to build a developed and civilized nation.

\section{Conceptual Framework}

The conceptual framework for JS projected here that encompasses five Independent variables $1=$ Growth and Promotion, $2=$ Salary and compensation, $3=$ Supervision and Leadership, $4=$ Working condition and 5=Work life balance. Dependent variable is teacher job satisfaction. This conceptual study consists of three types of factors which influence academician's work satisfaction. These are intrinsic, extrinsic and personal factors. On the bases of this conceptual framework this study develops following hypothesis and detailed discussion of these factors

\subsection{Motivational Factors}

These types of factors are almost deriving from university's working practices. Teachers come to know through daily involvement with students and their feedback, whether or not students have pulled out to some extent as an end result of education. Teacher's influencing power over the lecture room setting is also intrinsic factor (Lee et al., 1991). The others essential factors are the work nature, individual recognition and growth opportunities and work freedom. Professional autonomy increases the charisma of teaching work as a professional choice (Boe \& Gilford, 1992). Many young peoples motivated by the motivational factors toward academic profession (Choy et al., 1993). Padilla-Velez (1993) and Bowen (1980) described that possibility of Growth and promotion opportunities are changes in career development, and irrespective of the truth that the alteration probably will be upward or downward in condition. Finkelstein (1984) postulated that when faculties think about changing their jobs they do not think extrinsic factors like salary and financial benefits but they consider professional growth and opportunity for promotion as important factors. DeLeon and Tahir (1996) examined that possibilities of growth and chances for promotions are significant factors in faculty's satisfaction. Perceived promotional opportunities, training, good talent in future and opportunity for professional development each and every one of these factors plays significant role in work performance and job satisfaction by declining work anxiety. Such growth and promotion opportunities and other programs like these, reduce turnover by increasing faculty's satisfaction and by helping them to make out balance between their individual futures and the features of organization where they work (Kim, 2002; Sherman \& Bolander, 1992; Wright \& Davis, 2003).

H1: Growth and promotion opportunity provided by universities increase job satisfaction at University of Sindh Jamshoro

\subsection{Hygienic Factors}

There are some extrinsic factors like salary, working environment, supervisor behavior, peer relationship and job security and so other factors. In the past researches indicated that lack of resources, inadequate salaries, poor relationship with peer or supervision and poor working conditions are the forces that drive negative impact on teacher satisfaction. These forces also lead teacher's propensity toward higher turnover and low organizational 
commitment. Academicians leave their field, when they feel that working condition is not good (Choy et al., 1993). According to Sharma and Jyoti (2009-2010) intrinsic factors lead faculties toward teaching profession while extrinsic factors affect their level of motivation to retain in this field.

Padilla-Velez (1993) and Bowen (1980) defined supervision, as willingness or unwillingness to hand over accountabilities and facilitate subordinate to make them effective and efficient through enhancing their skills and knowledge. Ahuja (1976) described in his survey that employees feel dissatisfaction if their supervisor does not provide them required support, equipments, necessary training and well defined tasks. Foles et al. (2000) postulated that democratic direction makes employees happy with their work, because they do not like autocratic leadership and centralized decision making by manager. A research by Mackenzie investigated that $97 \%$ of the participant of research well thought-out that supervision as a most important motivational force for lecturer's morale (Huysman, 2008; Lumsden, 1998; Mackenzie, 2007; Miller, 1981).

\section{H2: Positive bbehaviors of HOD, positively affect faculty satisfaction at University of Sindh Jamshoro}

Working Condition means physical working place, facilities, and excellence of job as associated with work satisfaction (Padilla-Velez, 1993; Bowen, 1980). Plananandanond et al. (2004) described that working environments predict organizational performance. If there are appropriate physical surroundings at university, teacher will feel relaxed. Depressed operational surroundings like poor structure design and maintenance influence teacher's attitudes, which have strong impacts on educational performance. These factors also affect physical and mental health of both teachers and students too. Poor lighting, dysfunctional windows and gloomy rooms make teachers dissatisfy with their jobs (Schneider, 2003).

H3: There is positive association between good working environment and faculty satisfaction at University of Sindh Jamshoro

Salary and compensation include both financial and non financial benefits by organizations. These factors play an important role in employee satisfaction (Padilla-Velez, 1993; Bowen, 1980). Financial benefits play vital role in worker's satisfaction and these are most practiced and important challenges for HRM to motivate employees in an organization. According to Lawler (1971) that pay is observable fact of employee's expectation and the amount he actually receive from his employer.

H4: Good compensation packages and fair reward system positively affects faculty satisfaction at University of Sindh Jamshoro

\subsection{Work Life Balance}

Organizational revolution due to merger/acquisition and alteration in expertise has made work understanding a complex phenomenon. Today individuals are more engaging in their occupations with compare to last decades. The extra working hours, work anxiety, difficult jobs, use of complex expertise these are the common forces which made this difficult for employees to maintain equilibrium among their work and work satisfaction. These situations make it a big challenge for human resource management matter i.e. Work Life balance (WLB). Researcher explained that there are two main roles of person's life which they play in different stages of life.

Work satisfaction is significantly related with work to family or family to work interference. Burke (2000) gave details that generally workers feel satisfaction with their work if institutions provide cooperative environment in work life equilibrium. Prior studies investigated that organizational ethics supporting work-life balance, have strong affects on male and female faculty's satisfaction. Managerial and dedicated men show better work life satisfaction and family life satisfaction, more confidence, and enjoy emotional and psychological fulfillment (Burke, 2000; Jayaweera, 2005). Oswald (2002) examined in his study that job dissatisfaction occurrs; when work associated responsibilities turn out to be an obstacle in performing family tasks. Family oriented policies of organization help teachers to make equilibrium between workplace activities and house hold responsibilities, which increase their satisfaction towards their job (Kinnie et al., 2005). Human life consists of four stages of career development like inertia stage, middle stage, growth stage and retirement stage. In Middle and growth stages employees have to make too much effort to fulfill their family demands as well as workplace requirements; Along with their job they feel themselves more responsible for family and house hold responsibilities. These responsibilities may be like; their parents look after, child care, relative and friend's relations and so on. They have to pay attention to their family along with their work, so in these stages they feel difficulties to balance their personal life and work life.

Stevens (1995) explained that work satisfaction varies due to passage of time with variation in employee needs. Furthermore he described that these fluctuations take place in four steps: exploration, development, maintenance, and decline. The exploration time starts in beginning of a new condition, all the way through this condition, 
employees show symbols of a high enthusiasm, and spend lot of time on the job. In development stage, links and relationship are built up, strong associations with other are shaped, the complexity of the job increases, the aspiration to systematize revolution comes up, improvement of work-related ability is required, and feedback from superior, peers and management is appealed. The third part is the comprehensive and mystifying in which workers adjust human being ethics. They also interact more socially in their community. In decline step, changes occur in their satisfaction level, performance, self-confidence, and self-esteem. However, these variations are managed all the way through classification and measurement of those elements which affect job satisfaction. Work improvement also reduces job dissatisfaction in this stage (Stevens, 1995).

The term work life balance is described as equal requirement of both, family life and work life (Lockwood, 2003). However when disequilibrium between these two phenomena occurs, result is work life conflict. Consequently assuring sense of balance among job and personal life has become difficult task for organizations in recent fast and competitive global world. In 18th centuries industrial revolution made changes in work pattern along with the alteration in society demands. Work life conflict has become common phenomenon in recent organizations (Googins, 1991).

According to Duxbury et al. (2001) role overwork and role interference are two main aspects of work life balance. Role overwork is imbalance among personal life and work life responsibilities. Furthermore they described that work overload and work to family interference have negative relation with worker's satisfaction. Burchell (1999), Cabrita et al. (2006) and Fu et al. (2001) postulated that working hours directly effected work life balance. There is negative association between stress and worker's satisfaction (Yousef, 2002).

Preferences of work over personal life demand are called work to family interference. This aspect of job significantly affects committed male workers in organizations. Organizational transformations and increasing rate in products and service's may become reasons of work life conflict. Therefore human being needs additional income to sustain the same standard of living (Bar, 1993).

According to many scholars there are different perceptions of both male and female employees about work life balance (HR magazine, October 2005). Family to job interference is more in female than male faculties, because they spend much of their time at home (Scott, 2001), but work to family interference is common in male (Jacobs \& Gerson, 2000).

Pakistan is a growing economy where economic, social, political and legal instability changed the pattern of workplace and personal life of employees in organization. Therefore to maintaining the living standard, both husband and wife have to earn (Sauvé, 2002).

As globalization influenced Pakistani market, jobs have become more challenging and the working hours are also increased, the figures show that in 1971 to 1972 only $20.4 \%$ of employees were doing their work in 8 hours in a day. In 2004 this ratio has increased up to 30.9\% (Note 4). This increment in working hour's created disturbance between work place and family life, which resulted work to family interference that lead to work life conflict.

\section{H5: Work life balance strongly effects faculty satisfaction at University of Sindh jamshoro}

\subsection{Demographic Factors}

Demographic factors also effect the faculty job satisfaction same as other professions. These factors include age, gender, length of services, and marital status. According to Perie and Baker (1997) female are more satisfier with their work than male faculty and their satisfaction is less related with salary and fringe benefits. There is, $U$, shape association between work satisfaction and demographic factors such as age and experiences (Smith, 1982; Clark, Oswald, \& Warr, 1996). While according to (Stone, 2000; Haque, 2004) there is linear relation... Married peoples are more satisfied with their profession with compare to un-married people (Hertzberg et al., 1957).

\section{H6: Demographic factors strongly influence faculty satisfaction at Uniersity of Sindh Jamshoro}

\subsection{Research Gap}

Although previous researches gradually showed varieties of dimensions and variables that related to job satisfaction. However this study took into account some of intrinsic, extrinsic and one additional factor such as: work life balance to investigate work satisfaction of university academicians. This variable was not discussed directly along with work satisfaction of university academicians in Pakistani context. Furthermore study also examines causes that, why there is difference among employee's satisfaction, as discussed in previous study that, faculty between age thirty years and fifty years have different level of satisfaction, with compare to the faculty below thirty year of age and above fifty years of age (Sharma \& Jyoti, 2010). 


\section{Discussion}

Main aims of this exploratory study were to observe association between work satisfaction, and factors influencing it i.e. extrinsic, intrinsic factors of Herzberg (1957) and work life balance.

The study concluded relationship between employee's satisfaction and determinant factor with respect to employee's demographic characteristics. Study found that all independent factors promotion, supervisor's behavior, working environment, compensation and work life conflict are significant predictors of faculty's job satisfaction. Promotion Opportunities, possibility of growth and training programs positively affect faculty's work satisfaction. The contribution of other dimensions namely compensation and working environment are insignificant to both male and female faculty. Furthermore investigation also strengthens Herzberg's hypothesis that make a distinction between satisfier (motivational) and dissatisfies (hygienic) factors. Promotion chances and growth possibilities show considerable variation among male and female faculty's job satisfaction (Egbule, 2003).

Age wise differences were found most significant both in male and female faculty satisfaction. Equally male and female teachers were less satisfied with their job in middle age (development stage of life) as compare to after mid age (upholding stage of life) faculties.

The third phase is multifaceted and confusing in which an employee adjusts individual ethics. He/she also more interacts with community. In decline step, decline in satisfaction, performance, self-confidence, and self-esteems are occurring because of the end of career Steven (1995).

Time period in teaching profession significantly affects both male and female faculty job satisfaction. Faculties with more time period in teaching profession are much happier than new comers with minimum duration.

After all investigation study come up with an important findings that faculty in the middle age $(30<50)$ perceive their job in a different way as compare to faculty before thirty years of age and after fifty years of age $(30>50)$. This perception level of faculty is significantly affected by teacher's work life balance which strongly interferes in the age of 30 where inertia stage ends up and development stage starts. So teachers have to balance between workplace and personal life at this stage. Female faculties face many challenges during this equilibrium phenomenon between workplace and house hold job.

\section{Managerial Implications}

Head of Departements HOD in various departments in Univesity of Sindh could do think about several policy to provide supports to their faculty. Performing such measurement can be a first footstep to motivating faculty toward their jobs.

Management and policy makers should offer family-friendly policies to staff members that give confidence in their professions. Organizations must support faculties' especially female faculties to balance their workplace responsibilities along with house hold tasks. As discussed in start of this paper that teachers are the initiators, and they need management support, training \& development, better infrastructure and flexible rules and policies by organizations. So organization should design HR strategies in a way that their employees can also get maximum advantage of these strategies. Organizations must provide batter career development programs, which can increase employee satisfaction because satisfied employees are the important predictors of organizational performance and organizational commitment.

\section{Conclusions}

The current research examines the job satisfaction among faculty members at University of Sindh Jamshoro. To understand the concept it is necessary to study that what aspect influence upon faculty's satisfaction. Rationale of this conceptual study is to observe teacher's satisfaction at Universities in Pakistan. The study also explores the effects of these factors on faculty's work satisfaction with respect to their demographic characteristics. It was revealed that female faculty members are more satisfied compare with male faculty members. The faculty members in Univeersity of Sindh are most satisfied with their jobs. It was further revealed that faculty members in University of Sindh Jamshoro are more concerned about the issues of derth in security in the campus and various political pressures of students.

\section{References}

Ahuja, D. C. (1976). Mental health hazards among school teachers. The Education Review, 8, 155-157.

Bar, L. (1993). Basic facts of families in Canada past and present. Statistics Canada. 
Boe, E. E., \& Gilford, D. M. (1992). Teacher supply, demand, and quality. National Research Council, Washington, DC: National Academy Press.

Bohen, H. N., \& Anamaria, V. L. (1981). Balancing jobs and family life: Do flexible work schedules. Philadelphia: Temple University Press.

Bowen, B. E. (1980). Job satisfaction of teacher educators in agriculture. Unpublished doctoral dissertation, The Ohio State University, Columbus.

Bowran, J., \& Todd, K. (1999). Job stressor and job satisfaction in a major metropolitan public EMS service. Pre hospital and disaster medicine, 14(4), 236-239.

Brief, A. P. (1998). Attitudes in and round organizations. Sage: Thousand Oaks, CA

Brief. (1998). Deconstructing job satisfaction: separating evaluations, beliefs and affective experiences. Human Resource Management Review, 12, 173-194, 17.

Brief, A. P., \& Weiss, H. M. (2001). Organizational behavior: affect in the workplace. Annual Review of Psychology, 53(279-307), 282.

Burke, R. J., \& Green Glass, E. R. (1999). Work-Family Congruence and Work-Family Concerns among Nursing Staff. Canadian Journal of Nursing Leadership, 12(2), 21.

Cabrita, J., \& Perista, H. (2006). Measuring Job Satisfaction in Surveys-Comparative Analytical Report. European Foundation for the Improvement of Living and Working Conditions (ef0671).

Choy, S. P., Bobbitt, S. A., Henke, R. R., Horn, M. L. J., \& Lieberman, J. (1993). America's Teachers: Profile of a Profession. Washington, DC: U.S. Department of Education, Office of Educational Research and Improvement, National Center For Education Statistics, NCES 93-025.

Clark, A., Osward, A., \& Warr, P. (1996). Is job satisfaction U shaped. Journal of Occupational and Organizational Psychology, 69, 57-81. http://dx.doi.org/10.1111/j.2044-8325.1996.tb00600.x

DeLeon, L., \& Taher, W. (1996). Expectations and job satisfaction of local government Professionals. American Review of Public Administration, 26(4), 401-416. http://dx.doi.org/10.1177/027507409602600402

Duxbury, L., \& Higgins, C. (2001). Work Life Balance in the New Millennium: Where are we? Where we need to go? CPNR Discussion paper No. W/12 October.

Egbule, P. E. (2003). Factors related to job satisfaction of academic staff in Nigerian universities. Journal of Further and Higher Education, 27(2), 157-166. Retrieved from http://www.informaworld.com/smpp content $\sim$ content $=$ a 713677196 words $=$ factors $\% 7$ crelated $\% 7$ cjob\%7c satisfaction\&h ash $=2182297297$

Ezra, M., \& Deckman, M. (1996). Balancing work and family responsibilities: Flextime and child care in the federal government. Public Administration Review, 56(2), 1749. http://dx.doi.org/10.2307/977205

Finkelstein, M. J. (1984). The American Profession. A Synthesis of Social Inquiry since World War II. Columbus: Ohio State University.

Foels, R., Driskell, J., Mullen, B., \& Salas, E. (2000). The effect of democratic leadership on group member satisfaction: An interaction. Small Group Research, 31(6), 676-701. http://dx.doi.org/10.1177/104649640003100603

Fu, C. K., \& Shaffer, M. A. (2001). The Tug of Work and Family: Direct and Indirect Domain Specific Determinants of Wfc. Personnel Review, 30(5), 502-522. http://dx.doi.org/10.1108/EUM0000000005936

Gautam, M., Mandal, K., \& Dalal, R. S. (2006). Job satisfaction of faculty members of veterinary sciences: an analysis. Livestock Research for Rural Development, 18(7), 89.

Googins, B. K. (1991). Work/family conflicts: Private Lives-Public Responses, Auburn, Westport, CT.

Haque, M. I. (2004). Job satisfaction of Indian academicians: a study based on gender and age. The Indian Journal of Commerce, 57(2), 102-113.

Herman, R., Dawson, P., Dee, T., Greene, J., Maynard, R., \& Redding, S. (2008). Turnaroud chronically low-performing schools (NCEE 2008-4020). Retrieved from http://ies.ed.gov/ncee/wwc/pdf/practiceguides/Turnaround_pg_04181.pdf

Hertzberg, F., Mausner, B., Peterson, R. O., \& Campbell, D. E. (1957) Job Attitudes: Review of Research and Opinion, Psychological Services of Pittisberg, Pittisberg.

Herzberg, F., Mausner, B., \& Snyderman, B. B. (1959). The motivation to work. New York: John Wiley \& Sons. 
Hochschild, A. (1989). The second shift: Working parents and the revolution at home. New York: Viking.

Jacobs, J. A., \& Gerson, K. (2000). Do Americans feel overworked? Comparing ideal and actual working time. Work and Family: Research Informing Policy, Sage, Thousand Oaks, CA, pp. 71-96.

Jayawara, A. T. (2005). A Model of Linkages between Work Family Conflict, Job Satisfaction and Individual's.

Kim, S. (2002). Organizational support of career development and job satisfaction: A case study of the Nevada Operations Office of the Department of Energy. Review of Public Personnel Administration, 22(4), 276-294. http://dx.doi.org/10.1177/073437102237813

Kinnie, N., Hutchinson, S., Purcell, J., Rayton, B., \& Swart, J. (2005). Satisfaction with HR practices and commitment to the organization: why one size does not fit all. Human Resource Management Journal, 5(4), 9-29. http://dx.doi.org/10.1111/j.1748-8583.2005.tb00293.x

Lapierre, L. M., Spector, P. E., Allen, T. D., Poelmans, S., Cooper, C. L., O’Driscoll, M. P., ... Kinnunenh, U. (2008). Family-supportive organization perceptions, multiple dimensions of workfamily conflict, and employee satisfaction: A test of model across five samples. Journal of Vocational Behavior, 73(1), 92. http://dx.doi.org/10.1016/j.jvb.2008.02.001

Lawler, E. E. (1971). Pay and Organisational Effectiveness: A Psychological View, Mc Graw Hill, New York.

Lee, V. E., Dedrick, R. F., \& Smith, J. B. (1991). The effect of the social organization of schools on teachers' efficacy and satisfaction. Sociology of Education, 64, 190-208. http://dx.doi.org/10.2307/2112851

Lockwood, N. R. (2003). Work/Life Balance: Challenges and Solution 2003 Quarterly Report. HR Magazine, June.

Lumsden, L. (1998). Teacher morale. Eric. Digest, 120. Retrieved from $\mathrm{http}: / /$ cepm.uoregon.edu/publications/digests/digest120.html

Weiss, H. M. (1992). Deconstructing job satisfaction: separating evaluations, beliefs and affective experiences. Human Resource Management Review, 12(2), 173-194. http://dx.doi.org/10.1016/S1053-4822(02)00045-1 